\title{
Characteristics of Clustering and Switching in Verbal Fluency according to Healthy Elderly Group
}

\author{
Juyeong Kim ${ }^{\mathrm{a}}$, Hyunjoo Choi ${ }^{\mathrm{b}}$ \\ ${ }^{a}$ Osan children language clinic, Osan, Korea \\ ${ }^{b}$ Department of Communication Disorders, Korea Nazarene University, Cheonan, Korea
}

Correspondence: Hyunjoo Choi, PhD Department of Speech-Language Pathology, Korea Nazarene University, 48 Wolbong-ro, Seobuk-gu, Cheonan 31172, Korea

Tel: +82-41-570-1677

Fax: +82-41-570-7849

E-mail: hjchoi@kornu.ac.kr

Received: July 3, 2021

Revised: August 7, 2021

Accepted: August 11, 2021

This work was supported by the Ministry of Education of the Republic of Korea and the National Research Foundation of Korea (NRF2019S1A5A2A01035719).
Objectives: The purpose of this study was to investigate the characteristics of clusters and switches through verbal fluency tasks by different age groups among the elderly. Methods: Ninety-four healthy elderly adults participated in this study. The verbal fluency task consisted of semantic verbal fluency and phonemic verbal fluency. The categories of 'animal' and 'supermarket' were used for semantic fluency, and the categories $1 / \mathrm{k} /{ }^{\prime}, 1 / \mathrm{o} /{ }^{\prime}$ and $1 / \mathrm{s} /{ }^{\prime}$ were used for phonemic fluency. Results: First, there was a significant difference between the age groups. The number of correct responses in the verbal fluency task decreased as age increased. Second, the mean cluster size for verbal fluency did not show a significant difference among groups in tasks of semantic and phonemic verbal fluency. Third, the number of switches showed a significant difference between groups in semantic and phonemic verbal fluency. In the post-analysis results of semantic fluency, a significant difference was found in the category of 'animals' between the young-old and old-old age group, and a significant difference was found in the number of switches in the category of 'supermarket' between the middle-old and old-old age group. Finally, the semantic fluency task showed the highest frequency of perseverative error, and the phonemic fluency task showed the highest frequency of other errors. Conclusion: These results of this study are meaningful in investigating characteristics of cluster and switch as well as the performance of correct rate through the verbal fluency tasks according to the elderly group.

Keywords: Ageing, Verbal fluency, Clustering, Switching
정상적인 노화 과정에서 나타나는 다양한 인지기능의 변화 중 전두엽 구조와 기능은 다른 뇌 영역에 비해 가장 먼저 쇠퇴하는 것 으로 알려져 있다(Burda, 2010; Dempster, 1992). 이러한 노화로 인 한 전두엽 기능 저하는 주의력(attention), 집행기능(executive function) 및 문제해결 능력에 영향을 준다(Kempler, Teng, Dick, Taussig, \& Davis, 1998). 전두엽 기능의 저하와 함께 관련 언어기능 수행 에도 문제가 나타나는데, 이와 관련된 대표적 언어 과제 중 하나가 구어 유창성(verbal fluency) 과제이다. 구어 유창성 과제는 일반 노 인이나 신경언어장애 환자의 어휘산출과 관련한 인지기능 손상을 평가하는 데 유용하고, 노화나 신경학적 질환으로 인한 인지기능 의 변화를 민감하게 검출할 수 있는 과제로 알려져 있다(Audenaert et al., 2000; Choi, 2008). 구어 유창성 과제는 제한된 시간 동안
주어진 범주의 단어를 최대한 많이 산출하는 과제로, 단어인출 능 력 및 전두엽 집행기능뿐 아니라 주의력, 작업기억(working memory), 모니터링 능력 등 다양한 인지기능을 요구한다(Choi, 2012). 또 한, 구어 유창성 과제는 Boston Diagnostic Aphasia Examination (BDAE; Goodglass, Kaplan, \& Barresi, 2001)과 같이 언어기능을 종합적으로 평가하는 검사들에 포함되어 널리 사용되고 있다.

구어 유창성 과제는 주로 의미 유창성(semantic fluency) 과제와 음소 유창성(phonemic fluency) 과제로 구성되어 있으며, 구어 유창 성 평가를 위한 국내 표준화 검사인 한국판 통제단어연상검사(Korean version of Controlled Oral Word Association Test, K-COWAT; Kang, Chin, Na, Lee, \& Park, 2000)에 이 두 종류의 구어 유창 성 과제가 포함되어 있다. 구어 유창성 과제에서 주로 사용되는 의 
미 유창성 범주는 '동물'이나 '가게에서 살 수 있는 물건', '식물' 등 이며, 음소 유창성은 영어권에서 'F, 'A, 'S'를, 한국어에서는 ' ᄀ', 'O', ‘' 음소 범주를 많이 사용한다. 이러한 의미 유창성과 음소 유 창성 과제의 수행은 서로 다른 뇌 영역의 참여를 요구하는데, 의미 유창성의 경우 의미 기억(semantic memory)을 통한 의미체계의 활 성화를 담당하는 측두엽(temporal lobe) 기능이 중요하고, 음소 유 창성은 어휘-음운(lexical-phonemic) 경로를 통한 음운적 단서 활 용을 위한 전두엽(frontal lobe) 기능이 중요한 것으로 알려져 있다 (Baldo, Schwartz, Wilkins, \& Dronkers, 2006; Birn et al., 2010; Capitani, Laiacona, \& Barbarotto, 1999; Henry \& Crawford, 2004).

구어 유창성 과제의 일반적인 평가 방법은 산출된 정반응수를 구하는 것이다. 그러나 이러한 방식이 과제 수행 동안 기저에 일어 나고 있는 인지처리(cognitive process) 과정에 대한 정보를 충분히 제공해 주지 못하기 때문에(Troyer, 2000) 보다 정교한 채점 방식이 필요하며, 이를 위해 제안된 대표적인 분석 방법이 군집(clustering) 과 전환(switching) 분석이다(Troyer, Moscovitch, Winocur, Alexander, \& Stuss, 1998). Troyer 등(1998)에 의해 제안된 군집과 전환 은 군집수(the number of clusters), 평균 군집 크기(mean cluster size), 전환수(the number of switches), 하위 범주수(the number of subcategories) 등의 지표를 포함한다. 구어 유창성 과제에서 군집 크기가 크다는 것은 의미적으로 연관된 다양한 단어를 묶어서 반 응할 수 있다는 의미이며, 전환수가 크다는 것은 군집 사이의 전환 이 활발하게 이루어진다고 해석할 수 있다. 따라서 구어 유창성 과 제 수행에서의 군집과 전환 분석 결과는 대상자의 의미지식 구조 가 얼마나 조직화되어 있는지를 반영하는 지표가 되는데, 이러한 군집과 전환은 각각 서로 다른 인지적 처리 과정에 의존하는 것으 로 알려져 있다(Park et al., 2006; Troyer, Moscovitch, \& Winocur, 1997). 이와 관련된 선행 연구의 결과를 종합하면 군집은 하위영역 안에서 의미적으로 관련이 있는 단어를 유기적으로 산출하는 능력 으로 측두엽 기능과 주로 관련이 있으며, 전환은 해당 군집의 단어 가 고갈되었을 때 이를 대체하기 위해 또 다른 군집으로 이동하는 능력으로, 이는 단어산출 능력 및 인지적 유연성과 관련된 전두엽 이 주로 담당하는 것으로 알려져 있다(Ho et al., 2002; Troyer et al., 1998).

지금까지 구어 유창성 과제를 이용하여 다양한 대상자들의 군집 과 전환에 대한 연구들이 진행되어 왔다(Auriacombe et al., 1993; Baldo \& Shimamura, 1998). 우선, Park과 Yoon (2015)의 연구는 노 년층과 청년층을 대상으로 구어 유창성 과제를 진행하고, 두 집단 의 정반응수, 오류 빈도, 군집 크기, 전환수를 비교하였다. 그 결과, 의미 유창성 과제와 음소 유창성 과제 모두에서 노년층이 청년층
에 비해 유의하게 낮은 정반응수를 보였다. 또한, 의미 유창성 과제 와 음소 유창성 과제 모두에서 노년층이 청년층에 비해 평균 군집 크기가 더 크고, 전환수는 적은 것으로 나타났다. 반면, 일반 노인 과 난청 노인의 구어 유창성 과제 수행을 비교한 선행연구(Lee, 2019)에서는 평균 군집 크기에는 두 집단 간 유의한 차이는 없었으 며, 연령이 증가할수록 전환수가 감소한다고 보고하였다. 다음으 로, Troyer, Moscovitch, Winocur, Leach와 Freedman (1998)은 알 츠하이머형 치매 및 파킨슨병 환자를 대상으로 의미 유창성 '동물' 범주와 음소 유창성 ' $\mathrm{S}$ ' 범주 과제를 실시하여 정반응수, 평균 군집 크기와 전환수를 비교하였다. 그 결과 알츠하이머 치매 환자와 치 매를 동반한 파킨슨병 환자의 경우 일반 노인 집단에 비해 의미 유 창성과 음소 유창성 모두에서 정반응수가 낮았다. 또한, 군집과 전 환 분석에서 알츠하이머형 치매 환자의 경우 일반 노인에 비해 의 미 유창성에서의 군집과 전환수가 모두 제한적이었으며, 치매를 동 반한 파킨슨병 환자는 의미 유창성과 음소 유창성 모두에서 전환 수의 제한을 보였다. 반면, 치매를 동반하지 않은 파킨슨병 환자의 경우 의미 유창성, 음소 유창성 모두 일반 노인과 유의한 차이를 보 이지 않아 구어 유창성 과제의 수행 및 군집과 전환 능력의 손상은 치매와같은 인지기능 장애와 밀접한 관련이 있음을 알 수 있다.

마지막으로 구어 유창성 과제 수행에 있어서의 질적 능력을 평가 하기 위하여 오류 분석이 추가적으로 이루어져 왔다(Park et al., 2006). 구어 유창성 과제의 오류 유형을 살펴보면, 같은 단어를 2회 이상 산출하는 반복오류(perseverative error), 해당 범주에 속하지 않는 단어를 산출하는 침입오류(non-categorical error), 그 밖에 파 생어, 고유명사 비단어 산출 등의 오류를 들 수 있다. 구어 유창성 과 제에서 나타나는 오류 분석 결과를 살펴보면 우선, 의미 유창성 과 제에서는 노년층이 청년층보다 반복오류의 빈도가 높았으며, 침입 오류는 노년층과 청년층 모두에서 거의 나타나지 않아 집단 간의 차 이가 유의하지 않았다(Ki, 2006). 반면, 음소 유창성 과제에서는 노 년층이 청년층보다 침입오류의 빈도가 유의하게 높았으며, 반복오 류는 노년층과 청년층 모두에서 거의 나타나지 않아 집단 간 빈도 차이는 유의하지 않았다(Park \& Yoon, 2015). 다음으로 일반 노인, 알츠하이머형 치매 환자, 혈관성 치매 환자 집단의 구어 유창성 과 제의 오류를 분석한 Park 등(2006)의 연구에 따르면 일반 노인과 혈 관성 치매 환자에 비해 알츠하이머형 치매 환자들이 더 많은 반복오 류를 보였지만, 침입오류의 차이는 유의하지 않은 것으로 나타났다.

노화로 인한 생물학적, 심리적, 인지적 기능의 퇴화에 따른 언어 장애의 양상은 치매나 실어증으로 인한 의사소통장애와는 구별되 므로 일반 노인의 언어능력과 관련된 연구결과는 성인 신경언어장 애 환자의 평가 및 치료의 규준으로서 임상적 의의를 가진다(Kim, 
Juyeong Kim, et al. • Clustering and Switching in Verbal Fluency in Healthy Elderly

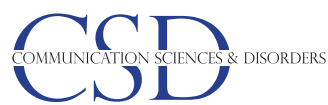

Hwang, Kim, \& Kim, 2013). 그러나 일반 노인의 구어 유창성 능력 을 살펴본 대부분의 선행연구들은 청년 집단과의 비교를 통하여 이루어졌으며, 정상적인 노화 과정에서 나타나는 구어 유창성 과제 의 수행력 및 군집과 전환 특성의 차이를 살펴보지 못하였다. 따라 서 본 연구에서는 일반 노인을 연소노인부터 고령노인까지 집단을 구분하여 구어 유창성 과제의 연령 집단별 수행력, 군집과 전환 특 성 및 오류 유형을 비교하는 것을 목적으로 하였다. 구체적인 연구 문제는 다음과 같다. 첫째, 구어 유창성 과제의 수행에서 연령 집단 에 따른 정반응수에 차이가 있는지 알아본다. 둘째, 구어 유창성 과 제 수행의 평균 군집 크기 및 전환수에 있어서 연령 집단에 따른 차 이가 있는지 알아본다. 셋째, 구어 유창성 과제 수행의 오류 유형별 빈도수에 연령 집단 간 차이가 있는지 알아본다.

\section{연구방법}

\section{연구대상}

본 연구는 경기 및 충남에 거주하는 55-85세의 일반 노인 94명을 대상으로 하였다. 연구에 따라 다양한 노인의 기준을 사용하는데, 본 연구에서는 상대적으로 젊은 연소노인을 대상에 포함시키기 위 하여 「고용상 연령차별금지 및 고령자 고용촉진에 관한 법률」에 의 한 노인의 기준인 55 세부터 대상자를 선정하였으며, 연령에 따른 집단은 55-60대(young-old, 연소노인), 70대(middle-old, 중간노 인), 80대(old-old, 고령노인)로 구분하였다. 일반 노인의 선정 기준 은 다음과 같다: 1) 한국판 정신상태 간이검사(Korean Version of Mini-Mental State Exam, K-MMES; Kang, 2006) 결과, 해당 연령 및 교육년수 규준에서 $16 \%$ ile (-1 SD) 이상인 자, 2) 실어증 선별검 사(Screening Test for Aphasia Neurologic-communication Disorders, STAND; Kim, Heo, Kim, \& Kim, 2009)의 하위검사인 '듣고 이해하기' 과제를 수행하는 데 어려움이 없는 자, 3) 신경과적, 정신 과적 질환의 경험이 없는 자, 4) 지시 따르기를 위한 시각 및 청각 등 감각에 문제가 없는 자, 5) 단축형 노인 우울 척도(Short form of Geriatric Depression Scale, SGDS; Cho et al., 1999) 결과 7점 이하 로 우울증이 없는 자, 6) 한국어를 모국어로 하는 자.

세 집단의 성비, 연령, 교육년수와 K-MMSE 점수의 기술통계치 는 Table 1에 제시하였다. 우선 집단 간 성비에 차이가 있는지 알아 보기 위하여 카이제곱 $\left(\chi^{2}\right)$ 분석을 실시한 결과 집단에 따른 성비 차 이는 유의하지 않았다 $\left(\chi^{2}=1.812, p>.05\right)$. 다음으로 집단에 따른 교 육년수 및 K-MMSE 점수에 차이가 있는지 알아보기 위해 일원분 산분석을 실시한 결과, 교육년수 $(F=4.386, p<.05)$ 에서 집단 간 유 의한 차이가 나타났다. 집단 간 교육년수 차이에 따른 사후분석
Table 1. Descriptive statistics of age, education level, and K-MMSE score in participants

\begin{tabular}{lcccc}
\hline & $\begin{array}{c}\text { Young-old } \\
\text { aged }^{\mathrm{a}}(\mathrm{N}=29)\end{array}$ & $\begin{array}{c}\text { Middle-old } \\
\text { aged }^{\mathrm{b}}(\mathrm{N}=29)\end{array}$ & $\begin{array}{c}\text { Old-old aged }^{\mathrm{c}} \\
(\mathrm{N}=36)\end{array}$ & $\begin{array}{c}\text { Group } \\
\text { comparison }\end{array}$ \\
\hline Gender (male:female) & $11: 18$ & $10: 19$ & $18: 18$ & $\mathrm{a}=\mathrm{b}=\mathrm{c}$ \\
Age (yr) & $62.28(4.69)$ & $76.34(2.74)$ & $82.75(1.68)$ & $\mathrm{a}>\mathrm{b}>\mathrm{c}$ \\
Education level (yr) & $10.55(3.94)$ & $8.45(2.74)$ & $8.06(3.68)$ & $\mathrm{a}>\mathrm{c}$ \\
K-MMSE score & $26.34(1.63)$ & $25.66(2.35)$ & $24.92(3.03)$ & $\mathrm{a}=\mathrm{b}=\mathrm{c}$ \\
\hline
\end{tabular}

K-MMSE $=$ Korean version of Mini-Mental State Examination (Kang, 2006).

(Scheffe)을 실시한 결과, 연소노인과 고령노인의 차이만 유의한 것 으로 나타났다. 세 집단의 K-MMSE 점수 $(F=2.278, p>.05)$ 에서의 차이는 유의하지 않은 것으로 나타났다.

\section{연구과제}

본 연구에서는 구어 유창성 과제로 한국판 통제단어연상검사 (Korean version of Controlled Oral Word Association Test, K-COWAT; Kang et al., 2000)를 사용하였다. K-COWAT은 1 분 동안 해 당 범주의 단어를 가능한 한 많이 산출하도록 하는 검사로 '동물' 과 '가게 물건' 범주의 단어를 산출하게 하는 의미 유창성 과제와 ' ᄀ', 'O', '스으로 시작하는 단어를 산출하도록 하는 음소 유창성 과제로 구성되어 있다.

구어 유창성 과제의 수행은 정반응수, 평균 군집 크기, 전환수, 오류 빈도로 분석하였다. 본 연구에서 사용한 분석 기준은 다음과 같다. 첫째, 정반응수는 해당 범주에 속하는 정확히 산출된 단어수 로 정의하였다. 자주 사용하는 외래어나 외국어는 정답으로 간주 하였으며, 오류 반응은 정반응수에 포함시키지 않았다. 또한, 파생 어의 경우 첫 반응만을 정반응으로 인정하였다. 둘째, 평균 군집 크 기는 군집의 크기를 군집수로 나누어 산출하였다. 의미 유창성 과 제에서 군집은 '연속적으로 나타난 단어가 같은 의미적 하위범주 에 속하는 경우’로 정의하였다. 군집을 평가하기 위한 ‘동물'과 '가 게 물건'의 하위범주 분류 및 예시는 Appendix 1에 제시하였다. 다 음으로 음소 유창성 과제에서의 군집은 '연속적으로 나타난 단어 가 같은 모음으로 시작되는 경우로 정의하였다. 셋째, 전환수는 의 미 유창성과 음소 유창성에서 과제 수행 중 한 군집에서 다른 군집 으로 이동한 수로 산출하였다. 마지막으로 오류 빈도는 유형별로 반복오류(같은 단어를 2 회 이상 산출), 침입오류(범주에 속하지 않 는 단어 산출), 기타오류(파생어, 명료도 저하, 비단어 오류, 고유명 사 등)로 나누었으며, 오류에 포함된 산출 단어는 정반응수, 평균 군집 크기, 전환수 산출에서 제외하였다. 


\section{연구절차}

본 연구는 나사렛대학교의 생명윤리위원회(IRB)의 승인(No. 2019-2-17)과 연구 대상자의 동의를 얻어 진행하였다. 검사는 방해 받지 않는 조용한 장소에서 연구자와 대상자가 일대일로 진행하였 다. 구어 유창성 과제의 진행은 K-COWAT의 표준화된 절차에 따 랐으며, 과제 수행 중 대상자의 반응은 모두 녹음하고 검사지에 바 로 기록하였다. 의미 유창성 과제의 경우, '동물' '가게 물건' 범주 순 으로 진행하였으며, 검사자는 대상자에게 "지금부터 1 분 동안 해 당 범주에 속하는 단어를 최대한 많이 산출해 보세요."라고 지시 한 뒤, 제한 시간 1 분 후에 과제를 중지하였다. 다음으로 음소 유창 성 과제는 'ᄀ', 'O', '손순으로 진행하였으며, “제가 어떤 글자를 말 한 뒤 '시작'하면 그 글자로 시작하는 단어를 떠오르는 만큼 최대한 많이 산출해 보세요. 예를 들어 '브으로 시작하는 단어를 말해주 세요' 하면 ‘바가지, 부자, 버섯’처럼 말해주시면 됩니다.”라고 지시 한 후 대상자가 과제에 대해 이해하였다고 판단되었을 때 본 검사 를 진행하였다.

신뢰도 분석은 전체 대상자의 $20 \%$ 에 해당하는 자료를 무작위로 추출하여 실시하였으며, 해당 자료를 제1평가자(연구자)와 제 2 평가 자(언어치료학 석사과정에 재학 중인 2급 언어치료사) 1 명이 각각 독 립된 공간에서 분석하였다. 두 평가자 간 일치율은 $92 \%$ 로 나타났다.

\section{통계분석}

수집된 자료는 통계분석 프로그램 SPSS 21.0 (Statistics Package for the Social Science, Version 21.0)으로 분석하였다. 우선, 의미 유 창성 과제는 '동물' '가게 물건'의 정반응수, 평균 군집 크기, 전환수 에 연소노인, 중간노인, 고령노인 집단에 의한 차이가 유의한지 알 아보기 위하여 교육년수를 공변량으로 한 다변량분석을 실시하고, 유의한 차이가 나타난 항목에 대하여 사후분석(Bonferroni)을 실 시하였다. 다음으로, 음소 유창성 과제는 음소의 총합에 대하여 정 반응수, 평균 군집 크기, 전환수에 연령 집단에 의한차이가 유의한 지 알아보기 위하여 교육년수를 공변량으로 한 일변량분석을 실시 하고, 유의한 차이가 나타난 항목에 대하여 사후분석(Bonferroni) 을 실시하였다. 마지막으로, 의미 유창성 과제와 음소 유창성 과제 에서 연령 집단에 따른 오류 유형(반복오류, 침입오류, 기타오류)의 빈도를 산출하였다.

\section{연구결과}

\section{노인 연령 집단에 따른 구어 유창성 과제의 수행}

노인 연령 집단에 따른 구어 유창성 과제의 정반응수를 Table 2 에 제시하였다. 우선, 의미 유창성의 '동물'과 '가게 물건' 범주에서 연령 집단에 따른 차이가 있는지 알아보기 위하여 교육년수를 공 변량으로 한 다변량분석을 실시한 결과, Wilks 람다값은 .765였으 며 집단에 따른 차이가 유의한 것으로 나타났다 $(p<.001)$. 사후분 석 결과 ‘동물'과 ‘가게 물건' 범주 수행력 모두에서 연소노인과 중 간노인, 연소노인과 고령노인의 차이는 유의한 것으로 나타났으나, 중간노인과 고령노인의 차이는 유의하지 않은 것으로 나타났다. 다 음으로 음소 유창성 과제 수행에 있어서 연령 집단에 따른 차이가 있는지 알아보기 위해 교육년수를 공변량으로 한 일변량분석을 실 시한 결과, 집단에 따른 차이가 유의하였다 $(F=5.541, p<.01)$. 사후 분석 결과, 음소 유창성 과제의 수행은 연소노인과 고령노인 집단 에서만 유의한 차이가 있는 것으로 나타났다.

\section{노인 연령 집단에 따른 구어 유창성 과제의 군집과 전환 특성}

노인 연령 집단에 따른 구어 유창성 과제 수행에서 나타난 평균 군집수의 기술통계치를 Table 3에 제시하였다. 우선, 의미 유창성 과제 '동물'과 '가게 물건' 범주에서 연령 집단에 따른 평균 군집 크 기에 유의한 차이가 있는지 알아보기 위하여 교육년수를 공변량으 로 한 다변량분석을 실시한 결과, Wilks 람다값은 2.079였으며 집 단에 따른 차이는 유의하지 않은 것으로 나타났다 $(p>.05)$. 다음으 로 음소 유창성 과제의 평균 군집수에서 연령 집단에 따른 차이가 유의한지 알아보기 위해 교육년수를 공변량으로 한 일변량분석을 실시한 결과, 역시 집단에 따른 차이는 유의하지 않았다 $(F=1.601$, $p>$.05).

Table 3. Mean (SD) on mean of cluster size in verbal fluency by age group

\begin{tabular}{lccc}
\hline & $\begin{array}{c}\text { Young-old } \\
\text { aged }\end{array}$ & $\begin{array}{c}\text { Middle-old } \\
\text { aged }\end{array}$ & $\begin{array}{c}\text { Old-old } \\
\text { aged }\end{array}$ \\
\hline Semantic fluency (animal) & $3.21(1.39)$ & $2.87(1.33)$ & $3.25(1.40)$ \\
Semantic fluency (supermarket) & $3.53(2.82)$ & $3.58(2.10)$ & $2.42(1.26)$ \\
Phonemic fluency (total) & $8.00(3.43)$ & $9.73(4.67)$ & $7.53(4.91)$ \\
\hline
\end{tabular}

Table 2. Mean (SD) of correct response for verbal fluency by age group

\begin{tabular}{|c|c|c|c|c|}
\hline & Young-old aged ${ }^{\mathrm{a}}$ & Middle-old aged ${ }^{\mathrm{b}}$ & Old-old aged ${ }^{c}$ & Group comparison \\
\hline Semantic fluency (animal) & $17.31(5.43)$ & $14.03(2.92)$ & 13.14 (3.98) & $a>b, a>c$ \\
\hline Semantic fluency (supermarket) & $20.79(5.33)$ & $15.62(4.59)$ & $14.06(4.49)$ & $a>b, a>c$ \\
\hline Phonemic fluency (total) & $25.79(11.14)$ & $22.24(5.58)$ & $19.06(7.09)$ & $a>c$ \\
\hline
\end{tabular}


Juyeong Kim, et al. • Clustering and Switching in Verbal Fluency in Healthy Elderly

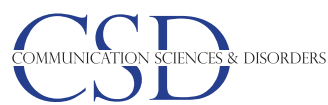

Table 4. Mean (SD) on number of switches in verbal fluency by age group

\begin{tabular}{lcccc}
\hline & Young-old aged $^{\text {a }}$ & Middle-old aged $^{\text {b }}$ & Old-old aged $^{\text {c }}$ & Group comparison \\
\hline Semantic fluency (animal) & $4.52(2.12)$ & $3.69(1.73)$ & $2.94(1.93)$ & a>c \\
Semantic fluency (supermarket) & $7.21(3.12)$ & $4.83(2.70)$ & $5.08(2.52)$ & a \\
Phonemic fluency (total) & $7.90(5.32)$ & $6.34(4.62)$ & $5.83(4.56)$ & a>c \\
\hline
\end{tabular}

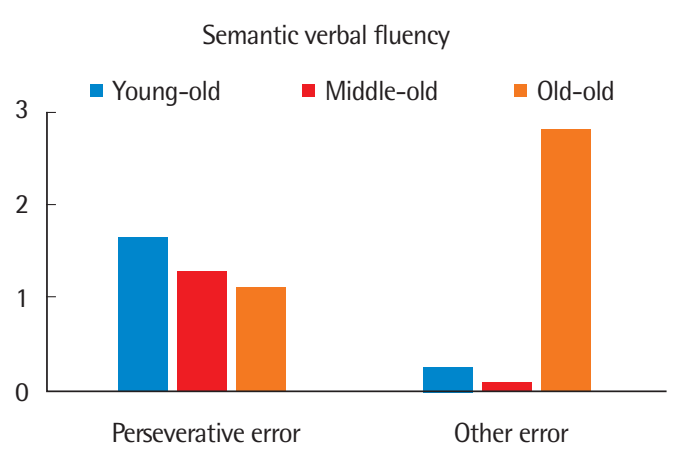

Figure 1. The frequency of error type in verbal fluency task by age group.

다음으로 구어 유창성 과제에서의 노인 연령 집단에 따른 전환 수의 기술통계치를 Table 4에 제시하였다. 결과를 살펴보면 우선, 의미 유창성 과제 수행에서 ‘동물' 범주에 비해 '가게 물건' 범주의 전환수가 모든 연령에서 높게 나타났다. 다음으로, 의미 유창성 과 제 '동물'과 ‘가게 물건' 범주에서 연령 집단에 따른 전환수에 유의 한 차이가 있는지 알아보기 위하여 교육년수를 공변량으로 한 다 변량분석을 실시한 결과, Wilks 람다값은 867 이었으며 집단에 따 른 차이가 유의한 것으로 나타났다 $(p<.001)$. 사후분석 결과 '동물' 범주에서는 연소노인과 고령노인의 전환수의 차이만 유의한 것으 로 나타났으며, '가게 물건' 범주에서는 연소노인과 중간노인에서 만 유의한 차이가 있었다. 또한, 음소 유창성 과제의 전환수에 있어 서 연령 집단에 따른 차이가 있는지 알아보기 위해 교육년수를 공 변량으로 한 일변량분석을 실시한 결과, 집단에 따른 차이가 유의 하였다 $(F=4.837, p<.01)$. 사후분석 결과 연소노인과 고령노인의 전환수 차이만 유의한 것으로 나타났다.

\section{노인 연령 집단에 따른 구어 유창성 과제의 오류 유형별 빈도}

의미 유창성, 음소 유창성 과제에서 나타난 노인 연령 집단에 따 른 유형별 오류 빈도의 평균을 Figure 1에 제시하였다. 우선, 의미 유창성 과제에서 연소노인과 중간노인은 반복오류를 가장 많이 보 였으며, 고령노인의 경우 기타오류의 빈도가 가장 높았다. 의미 유 창성 과제에서의 침입오류는 세 집단 모두에서 출현하지 않았다. 다음으로 음소 유창성 과제에서는 모든 집단에서 기타오류, 반복 오류, 침입오류 순으로 많이 나타났다.

\section{논의 및 결론}

본 연구는 일반 노인을 대상으로 구어 유창성 과제를 실시하여 연령 집단에 따른 수행 차이, 군집 및 전환 특성 및 오류 유형을 알 아보는 것을 목적으로 하였다. 구체적인 연구결과는 다음과 같다. 첫째, 의미 유창성, 음소 유창성 과제의 정반응수 모두 집단 간 유 의한 차이가 나타나 연령이 증가할수록 구어 유창성 과제의 수행 력이 제한됨을 알 수 있다. 구어 유창성 과제에서 연령이 증가하면 수행력이 낮아진다는 본 연구의 결과는 기존의 연구결과와 일치한 다(Kang et al., 2000; Mathuranath et al., 2003). 이러한 결과는 노 화로 인한 다양한 인지적 처리 과정의 변화와 관련지어 설명할 수 있다. 우선, 노화로 인하여 인지적 처리 속도가 감소하며(Salthouse, 1996), 이러한 인지적 처리 속도 감소로 인해 단어 재인 속도 또한 지연되어 시간 제한을 가진 구어 유창성 과제의 수행력이 저하되는 것으로 해석할 수 있다(Burke \& Shafto, 2004). 다음으로 일반 노인 은 노화로 인해 다른 뇌 영역보다 전두엽의 구조와 기능이 가장 먼 저 쇠퇴하고, 그로 인해 전두엽 기능과 밀접한 관련이 있는 구어 유 창성 과제의 수행이 제한된다고 알려져 있다(Miceli, Caltagirone, Gainotti, Masullo, \& Silveri, 1981). 또한, 정보를 저장하고 조작하 는 작업기억 능력은 단어인출과 관련이 있는데, 노화로 인한 작업 기억의 제한이 구어 유창성 과제의 수행력을 저하시킨다는 연구결 과(Kim, 2016)에 빗대어 본 연구의 결과를 해석할 수 있다. 기존의 연구에서 구어 유창성 과제는 경도인지장애(Mild Cognitive Impairment)나 초기 알츠하이머형 치매(dementia of Alzheimer's 
type)와 같이 인지장애를 가진 환자와 일반 노인을 구별하는 가장 민감한 과제로 알려져 있는데(Choi, 2011; Cooper, Lacriz, Weiner, Rosenberg, \& Cullum, 2004), 이는 구어 유창성 과제가 다양한 인 지능력을 복합적으로 요구하는 과제로 인지기능의 변화를 민감하 게 검출하기 때문이다. 본 연구의 결과는 구어 유창성 과제가 인지 장애를 가진 환자뿐 아니라 정상적인 노화로 나타나는 인지기능의 변화를 구별하는 데에도 유용함을 시사한다.

구어 유창성 과제 수행력의 집단 간 차이를 더 구체적으로 살펴 보기 위하여 사후분석을 실시한 결과 우선, 의미 유창성 과제에서 는 연소노인과 중간노인, 연소노인과 고령노인의 차이는 유의하였 지만 중간노인과 고령노인의 차이는 유의하지 않은 것으로 나타났 다. 이를 통해 상대적으로 젊은 5.60대의 연소노인에 비하여 70대 이상의 노인에게서 의미 유창성 과제 수행력에서 급격하게 제한됨 을 알 수 있다. 이러한 결과는 50대에서 90 대까지의 노인의 연령 집 단에 따른 이름대기 능력을 비교에서 한 Verhaegen과 Poncelet (2013)의 연구에서 이름대기 능력의 저하가 급격하게 나타나는 시 기를 70 대 이상이라고 보고한 것과 맥락을 같이한다. 의미 유창성 과 달리 음소 유창성 과제 수행의 사후분석 결과 연소노인과 고령 노인 집단 간에서만 유의한 것으로 나타났다. 이러한 차이가 나타 난 원인은 다음과 같이 유추할 수 있다. 우선, 음소 유창성 과제는 의미 유창성 과제에 비해 난이도가 높아 노화로 인한 인지기능의 변화를 더 민감하게 반영하기 때문에 이미 중간노인의 단계에서도 수행이 상당히 저하되어 있다고 생각할 수 있다. 이와 관련하여 노 화로 인해 철자 정보에 대한 활성화가 저하되어(Burke, MacKay, Worthley, \& Wade, 1991) 고령자의 경우 의미 유창성에 비해 음소 유창성 과제 수행에서 유창하게 막힘없이 연속하여 단어를 산출 하는 빈도가 제한적이라고 알려져 있다(Park \& Yoon, 2015). 다음 으로, 음소 유창성 과제는 자소에 따른 단어를 생성하는 과제로 선 행연구에 의하면 교육년수에 의한 영향이 큰 과제로 알려져 있다 (Choi, 2012; Kang et al., 2000; Peach \& Shapiro, 2012). 그러나 본 연구에서는 연령 집단에 따른 차이를 살펴보기 위하여 교육년수 를 공변량으로 통제했기 때문에 교육년수에 의한 음소 유창성 과 제의 수행 차이가 상대적으로 상쇄되어 의미 유창성 과제의 결과 와는 달리 연령 차이가 많은 연소노인과 고령노인 집단에서의 차이 만 유의하게 나타난 것으로 여겨진다.

둘째, 노인 연령 집단에 따른 구어 유창성 과제의 평균 군집수와 전환수의 차이를 알아본 결과 평균 군집수는 의미 유창성, 음소 유 창성 모두에서 유의한 차이를 보이지 않았으며, 전환수는 의미 유 창성, 음소 유창성 모두에서 연령 증가에 따른 전환수의 감소 추세 가 유의한 것으로 나타났다. 이와 관련하여 구어 유창성 과제의 군
집 크기와 관련된 특성을 살펴본 기존 연구들의 결과는 혼재되어 있다. 일부 연구에서는 연령이 증가하면 평균 군집 크기가 감소한 다고 한 반면, 다른 연구에서는 평균 군집 크기에서는 연령에 의한 차이가 없다고 보고하였다. 이러한 연구결과의 차이는 연구 대상자 의 차이에 의한 것으로 생각해 볼 수 있다. 우선 청년층과 노년층의 평균 군집 크기를 비교한 Park과 Yoon (2015)의 연구에서는 청년 층에 비해 노년층의 평균 군집 크기가 작다고 하였으며, 일반 노인 과 난청 노인의 구어 유창성 능력을 비교한 Lee (2019)의 연구에서 는 두 집단의 평균 군집 크기의 차이는 유의하지 않다고 보고하였 다. 평균 군집 크기에서 집단에 따른 유의한 차이가 없다는 결과를 보고한 연구들은 개인마다 단어산출 시 다양한 전략을 사용하며, 사용 전략에 따라 군집 크기와 전환수의 결과가 상이할 수 있다고 주장한다(Troyer et al., 1997). 일반적으로 구어 유창성 과제 수행 에서 전환수가 증가하면 평균 군집 크기가 감소하며, 전환수가 감 소하면 평균 군집 크기는 증가한다. 즉, 구어 유창성 과제 수행에서 군집의 크기를 늘리는 전략을 사용하면 상대적으로 전환수가 줄 어들며, 전환수를 늘리는 전략을 사용하면 상대적으로 군집의 크 기는 줄어든다. 따라서 평균 군집 크기는 연령, 인지기능과 관련한 변수보다 군집 크기 증가 전략과 전환수 증가 전략을 사용하는 대 상자가 연구에 얼마나 포함되었는가에 따라 다른 결과를 보일 수 있다고 해석할 수 있다. 반면에 전환수는 일반적으로 본 연구의 결 과와 같이 연령이 증가함에 따라 감소하는 것으로 알려져 있다. 이 러한 전환수의 감소는 노화로 인한 전두엽 기능의 저하로 인한 단 어산출 능력 저하 및 인지적 유연성의 제한과 관련하여 설명할 수 있다(Park \& Yoon, 2015). 본 연구에서 가장 높은 수행을 보인 '가 게 물건' 범주의 전환수가 다른 범주에 비해 높고, 고령노인의 수행 이 중간노인에 비해 제한적이지 않은 이유 또한 과제의 친숙도가 높 고 난이도가 낮아 인지적 부담이 낮았기 때문인 것으로 설명할 수 있다. 또한, 구어 유창성 과제에서의 전환 능력은 주로 전두엽 기능 과 밀접한 관련이 있는 것에 반해 의미기억과 음운경로의 접근 능 력을 요구하는 군집 능력은 측두엽 기능의 영향을 받는 것으로 알 려져 있다(Troyer et al., 1997; Troyer, Moscovitch, Winocur, Leach, \& Freedman, 1998). 따라서, 구어 유창성 과제의 전환 능력에 노화 로 인한 영향이 큰 것은 일반 노인의 경우 초기부터 다른 뇌 영역에 비해 전두엽 기능의 저하가 두드러진다는 연구결과와 맥락을 같이 한다(Burda, 2010).

마지막으로 의미 유창성 과제와 음소 유창성 과제의 수행에서 나타난 유형별 오류 빈도에 대한 연령 집단별 특성을 살펴보았다. 우선, 의미 유창성 과제에서 연소노인과 중간노인은 반복오류를 가장 많이 보였으며, 고령노인의 경우 기타오류의 빈도가 가장 높 
Juyeong Kim, et al. • Clustering and Switching in Verbal Fluency in Healthy Elderly

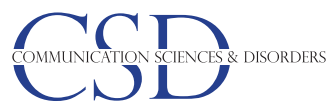

았다. 의미 유창성 과제에서의 침입오류는 세 집단 모두에서 출현 하지 않았다. 이는 의미 유창성 과제를 수행할 때 주로 나타나는 오 류는 다른 범주에 있는 단어를 산출하기보다는 반복적으로 동일 한 단어를 산출하는 오류를 보인다는 선행연구와 일치하며 $(\mathrm{Ki}$, 2006), 침입오류는 고령노인에게서도 나타나지 않음을 알 수 있다. 이렇듯 의미 유창성 과제에서 반복오류가 많이 나타나는 이유는 다음과 같이 유추할 수 있다. 첫째, 의미 유창성 과제에서는 음소 유창성 과제에 비해 산출되는 단어수가 월등히 많아 작업기억의 용량이 증가하며(Park \& Yoon, 2015), 따라서 이전에 산출한 단어 를 다시 산출하는 오류가 나타날 수 있다. 둘째, 의미 유창성 과제 수행 중 군집의 전환이 나타날 때 다른 군집에 동일한 단어가 포함 될 수 있어 반복오류가 나타난 것으로 여겨진다(예, 돌고래는 동물 원에서 볼 수 있는 동물과 물에서 사는 동물에 모두 포함). 의미 유 창성과 달리 음소 유창성 과제에서는 침입오류가 일부 나타났는데, 이는 노화로 인한 인지적 변화로 기억 연결이 약해져 목표 정보 및 철자 정보에 대한 활성화가 저하되고(Burke et al., 1991), 이로 인해 음소 유창성 과제 시 단어의 철자가 잘 기억나지 않거나(Park \& Yoon, 2015), 의미적 관련 단어가 떠올랐을 때 이를 억제하는 능력 의 결함과 관련이 있다(Schaie \& Willis, 2010). 이와 더불어, 의미 유창성 과제에 비해 음소 유창성 과제의 난이도가 높아 침입오류 가 출현했을 가능성을 생각해 볼 수 있다. 의미 유창성 과제는 확실 하게 의미 범주가 고정되어 있는 반면에 음소 유창성 과제의 범주 는 다양한 모음을 결합해 산출하거나 같은 모음이지만 다양한 의 미적 범주에 속하는 단어들을 산출해야 하기 때문에 의미 유창성 과제에 비해 난이도가 높고, 이로 인해 음소 유창성 과제에서 침입 오류가 일부 나타났다고 해석할 수 있다. 또한, 목표 음소와 유사한 음운자질에 대한 산출 오류(깍두기, 쌀) 및 의미적 연관 단어의 산 출 오류(김치-물김치)가 많이 나타났으며, 추가분석 결과 침입오류 중 유사한 음운자질에 대한 산출 오류와 의미적 연관 단어 산출 오 류의 비율은 55:45 정도인 것으로 나타났다. 다만, 연령이 증가하면 서 이러한 침입오류의 출현 빈도는 증가하지만 한 개인이 여러 개의 침입오류를 보이는 개인적 특성도 반영된 결과이므로 해석에 유의 할 필요가 있다. 본 연구에서는 반복오류와 침입오류를 제외한 파 생어, 비단어, 고유명사를 기타오류로 분석하였는데, 기타오류 역시 음소 유창성 과제에서 높은 빈도를 보였다. 이는 음소 범주에 속하 는 동사를 산출한 다음 그 동사의 파생어를 산출(예: 가다, 갑니다, 갔다 등)하거나(기타오류의 약 $30 \%$ ) 음소 범주에서 사용한 'ㄱ'과 'O' 범주의 경우 고유명사인 사람의 성(예: 김OO, 이OO)으로 시작 하는 단어가 많이 산출된 것(기타오류의 약 $23 \%$ )과 관련이 있었다. 본 연구는 정상 노인을 연령 집단으로 구분하여 구어 유창성 과
제의 노화에 따른 수행력 차이와 군집과 전환 특성을 알아보았다. 연소노인부터 고령노인까지의 구어 유창성 과제의 수행력을 비교 하여 노화로 인한 변화를 면밀히 살펴본 점, 구어 유창성 과제의 수 행력뿐 아니라 군집과 전환 특성, 오류 유형을 연령별로 비교한 점 등을 본 연구의 의의로 생각해 볼 수 있다. 그러나, 보다 다양한 의 미 범주 및 음소 범주의 과제를 사용하여 범주 난이도 및 단어 빈도 에 따른 차이를 비교하지 못한 점, 85세 이상의 초고령 노인의 수행 특성을 비교하지 못한 점 등을 연구의 제한점으로 들 수 있다. 앞으 로는 이러한 부분을 보완한 연구가 다양하게 진행되기를 기대한다.

\section{REFERENCES}

Audenaert, K., Brans, B., Van Laere, K., Lahorte, P., Versijpt, J., van Heeringen, K., \& Dierckx, R. (2000). Verbal fluency as a prefrontal activation probe: a validation study using $99 \mathrm{~m}$ Tc-ECD brain SPET. European Journal of Nuclear Medicine, 27(12), 1800-1808.

Auriacombe, S., Grossman, M., Carvell, S., Gollomp, S., Stern, M. B., \& Hurtig, H. I. (1993). Verbal fluency deficits in Parkinson's disease. Neuropsychology, 7(2), 182-192.

Baldo, J. V., Schwartz, S., Wilkins, D., \& Dronkers, N. F. (2006). Role of frontal versus temporal cortex in verbal fluency as revealed by voxel-based lesion symptom mapping. Journal of the International Neuropsychological Society, 12(6), 896-900.

Baldo, J. V., \& Shimamura, A. P. (1998). Letter and category fluency in patients with frontal lobe lesions. Neuropsychology, 12(2), 259-267.

Birn, R. M., Kenworthy, L., Case, L., Caravella, R., Jones, T. B., Bandettini, P. A., \& Martin, A. (2010). Neural systems supporting lexical search guided by letter and semantic category cues: a self-paced overt response fMRI study of verbal fluency. Neuroimage, 49(1), 1099-1107.

Burda, A. N. (2010). Communication and swallowing changes in healthy aging adults. Sudbury, MA: Jones \& Bartlett Learning.

Burke, D. M., MacKay, D. G., Worthley, J. S., \& Wade, E. (1991). On the tip of the tongue: what causes word finding failures in young and older adults? Journal of Memory and Language, 30(5), 542-579.

Burke, D. M., \& Shafto, M. A. (2004). Aging and language production. Current Directions in Psychological Science, 13(1), 21-24.

Capitani, E., Laiacona, M., \& Barbarotto, R. (1999). Gender affects word retrieval of certain categories in semantic fluency tasks. Cortex, 35(2), 273278.

Cho, M. J., Bae, J. N., Suh, G. H., Hahm, B. J., Kim, J. K., Lee, D. W., \& Kang, 
M. H. (1999). Validation of geriatric depression scale, Korean version (GDS) in the assessment of DSM-III-R major depression. Journal of Korean Neuropsychiatric Association, 38(1), 48-63.

Choi, H. J. (2008). A comparison of the performances of confrontation naming test and verbal fluency task in patients with prodromal Alzheimer's disease and mild Alzheimer's disease. Speech Sciences, 15(2), 111-118.

Choi, H. (2011). Detecting language deficits in patients with mild cognitive impairment through verbal fluency and picture description tasks. Korean Journal of Communication \& Disorder, 16(2), 171-184.

Choi, H. (2012). Performances of verbal fluency task in normal elderly: effects of gender and educational level by categories. Journal of Speech-Language and Hearing Disorders, 21(2), 37-52.

Cooper, D. B., Lacriz, L. H., Weiner, M. F., Rosenberg, R. N., \& Cullum, C. (2004). Category fluency in mild cognitive impairment: reduced effect practice in test-retest conditions. Alzheimer's Disease and Associative Disorders, $18(3), 120-122$.

Dempster, F. N. (1992). The rise and fall of the inhibitory mechanism: toward a unified theory of cognitive development and aging. Developmental Review, 12(1), 45-75.

Goodglass, H., Kaplan, E., \& Barresi, B. (2001). BDAE-3: Boston Diagnostic Aphasia Examination (3rd ed.). Philadelphia, PA: Lippincott Williams \& Wilkins.

Henry, J. D., \& Crawford, J. R. (2004). A meta-analytic review of verbal fluency performance following focal cortical lesions. Neuropsychology, 18(2), 284-295.

Ho, A. K., Sahakian, B. J., Robbins, T. W., Barker, R. A., Rosser, A. E., \& Hodges, J. R. (2002). Verbal fluency in Huntington's disease: a longitudinal analysis of phonemic and semantic clustering and switching. Neuropsychologia, 40(8), 1277-1284.

Kang, Y. W. (2006). A normative study of the Korean-Mini Mental State Examination (K-MMSE) in the elderly. Korean Journal of Psychology, 25(2), $1-12$.

Kang, Y. W., Chin, J. H., Na, D. L., Lee, J, H., \& Park, J. S. (2000). A normative study of the Korean version of Controlled Oral Word Association Test (COWAT) in the elderly. The Korean Journal of Psychology, 25(2), 385-392.

Kempler, D., Teng, E. L., Dick, M., Taussig, I. M., \& Davis, D. S. (1998). The effects of age, education, and ethnicity on verbal fluency. Journal of the International Neuropsychological Society, 4(6), 531-538.

Ki, Y. O. (2006). Errors and characteristics of verbal fluency from healthy Koreans over the age of 65 (Master's thesis). Yonsei University, Seoul, Korea.
Kim, J. W., Hwang, J. H., Kim, S. R., \& Kim, H. H. (2013). Differences in attention and naming ability with age in the elderly. Journal of Speech-Language and Hearing Disorders, 22(3), 25-44.

Kim, J. Y. (2016). Variables affecting on generative naming of middle-aged and elderly people: working memory, executive function, education level (Master's thesis). Yonsei University, Seoul, Korea.

Kim, H. H., Heo, J. H., Kim, D. Y., \& Kim, J. W. (2009). Screening Test for Aphasia and Neurologic-communication Disorder (STAND). Seoul: Hakjisa.

Lee, S. J. (2019). Clustering and switching on verbal fluency in older adults with hearing loss. Korean Academy of Audiology, 15(4), 293-301.

Mathuranath, P. S., George, A., Cherian, P. J., Alexander, A., Sarma, S. G., \& Sarma, P. S. (2003). Effects of age, education and gender on verbal fluency. Journal of Clinical and Experimental Neuropsychology, 25(8), 1057-1064.

Miceli, G., Caltagirone, C., Gainotti, G., Masullo, C., \& Silveri, M. C. (1981). Neuropsychological correlates of localized cerebral lesions in non-aphasic brain-damaged patients. Journal of Clinical and Experimental Neuropsychology, 3(1), 53-63.

Park, J., Kang, Y., Chang, E. J., Oh, E., Yu, K. H., \& Lee, B. C. (2006). Clustering and switching on verbal fluency in vascular dementia and dementia of the Alzheimer's type. Korean Journal of Communication \& Disorders, 11(3), 99-112.

Park, J. J., \& Yoon, J. H. (2015). Word-finding strategies on generative naming in normal elderly. Journal of Rehabilitation Research, 19(2), 339-360.

Peach, R. K., \& Shapiro, L. P. (2012). Cognition and acquired language disorders: an information processing approach. Maryland Heights, MO: Mosby.

Salthouse, T. A. (1996). The processing-speed theory of adult age differences in cognition. Psychological Review, 103(3), 403-428.

Schaie, K. W., \& Willis, S. L. (Eds.). (2010). Handbook of the psychology of aging. Burlington, MA: Academic Press.

Troyer, A. K. (2000). Normative data for clustering and switching on verbal fluency tasks. Journal of Clinical and Experimental Neuropsychology, 22(3), $370-378$.

Troyer, A. K., Moscovitch, M., \& Winocur, G. (1997). Clustering and switching as two components of verbal fluency: evidence from younger and older healthy adults. Neuropsychology, 11(1), 138-146.

Troyer, A. K., Moscovitch, M., Winocur, G., Alexander, M. P., \& Stuss, D. (1998). Clustering and switching on verbal fluency: the effects of focal frontal-and temporal-lobe lesions. Neuropsychologia, 36(6), 499-504.

Troyer, A. K., Moscovitch, M., Winocur, G., Leach, L., \& Freedman, M. (1998). Clustering and switching on verbal fluency tests in Alzheimer's and Par- 
Juyeong Kim, et al. • Clustering and Switching in Verbal Fluency in Healthy Elderly

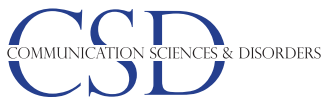

kinson's disease. Journal of the International Neuropsychological Society, 4(2), 137-143.

Verhaegen, C., \& Poncelet, M. (2013). Changes in naming and semantic abil- ities with aging from 50 to 90 years. Journal of the International Neuropsychological Society, 19(2), 119-126. 
Appendix 1. 구어 유창성 과제 하위범주 분류 및 예시

〈의미 유창성 과제 '동물' 하위범주 분류 및 예시〉

\begin{tabular}{|c|c|}
\hline 하위범주 & 범주에 따른 분류 예시 \\
\hline \multicolumn{2}{|l|}{ 서식환경 } \\
\hline 동물원에서 볼 수 있는 동물 & 사자, 기린, 원숭이, 호랑이, 코뿔소, 악어, 타조, 코끼리, 곰 등 \\
\hline 물속에서 사는 동물 & 돌고래, 펭귄, 바다사자, 상어, 거북이, 고래, 오징어, 조개 등 \\
\hline 야생동물 & 멧돼지, 고라니, 너구리, 다람쥐, 노루, 뱀 등 \\
\hline 애완동물/가축 & 개, 고양이, 토끼, 소, 말, 오리, 돼지, 염소, 닭 등 \\
\hline \multicolumn{2}{|l|}{ 동물 종류 } \\
\hline 곤충/거미류 & 모기, 개미, 거미, 메뚜기, 나비 등 \\
\hline 조류 & 참새, 까치, 까마귀, 앵무새, 제비 등 \\
\hline 양서류/파충류 & 개구리, 도마뱀, 뱀, 악어, 두꺼비 등 \\
\hline 포유류 & 돼지, 염소, 양, 소, 말, 코끼리 등 \\
\hline 어류 & 상어, 고등어, 갈치, 조기, 고래 등 \\
\hline 영장류 & 원숭이, 침팬지, 오랑우탄 등 \\
\hline 기타 & 거북이-토끼, 고양이-쥐, 십이지 \\
\hline
\end{tabular}

〈의미 유창성 과제 '가게 물건' 하위범주 분류 및 예시〉

\begin{tabular}{ll}
\hline 하위범주 & \multicolumn{1}{c}{ 범주에 따른 분류 예시 } \\
\hline 과일 & 바나나, 사과, 포도, 귤, 오렌지, 수박, 배, 복숭아, 블루베리 등 \\
야채 & 당근, 시금치, 토마토, 파, 양파, 마늘, 상추, 배추, 콩나물 등 \\
유제품 & 우유, 치즈, 요거트, 버터 등 \\
육류 및 어류 & 소고기, 돼지고기, 닭고기, 햄, 고등어, 갈치, 연어 등 \\
간식 및 과자 & 사탕, 케이크, 아이스크림, 빵, 쌀과자 등 \\
가공식품 & 통조림, 김, 햄, 소세지, 햇반 등 \\
음료 및 주류 & 커피, 우유, 주스, 물, 소주, 맥주 등 \\
의류 및 속옷 & 바지, 티, 셔츠, 양말, 팬티, 모자 등 \\
양념류 & 소금, 설탕, 간장, 식용유, 된장, 고추장 등 \\
가전제품 & $\mathrm{TV}$, 컴퓨터, 세탁기, 냉장고, 에어컨 등 \\
개인용품 및 가재도구 & 수건, 치약, 칫솔, 약, 휴지, 세제, 비누 등 \\
주방도구 & 칼, 냄비, 주전자, 후라이팬, 국자, 랩, 비닐장갑 등 \\
곡류 & 쌀, 콩, 팥, 보리 등 \\
\hline
\end{tabular}




\section{국문초록}

\section{노인 연령 집단에 따른 구어 유창성 과제에서의 군집과 전환 특성}

\section{김주영 $\cdot$ 최현주 ${ }^{2}$}

${ }^{1}$ 오산서울어린이병원, ${ }^{2}$ 나사렛대학교 언어치료학과

배경 및 목적: 본 연구는 연소노인부터 고령노인까지 일반 노인을 연령 집단으로 구분하여 구어 유창성 과제의 수행력, 군집과 전환 특 성, 오류 유형의 차이를 알아보는 것을 목적으로 하였다. 방법: 55-85세 일반 노인 94명을 연구대상으로 하였다. 구어 유창성 과제 중 의 미 유창성은 ‘동물', '가게 물건' 범주를, 음소 유창성은 ' 7 ', ‘O', '슴음소 범주를 사용하여, 각 1 분 동안 해당 범주의 단어를 산출하도록 하였다. 결과: 첫째, 의미 유창성, 음소 유창성 과제 모두에서 연령이 증가함에 따라 수행력이 저하되었다. 둘째, 평균 군집 크기는 의미 유창성, 음소 유창성 과제 모두에서 연령 집단 간 차이가 유의하지 않았다. 셋째, 전환수는 의미 유창성, 음소 유창성 과제 모두에서 연 령 집단 간 차이가 유의하였으며, 연령이 증가함에 따라 감소하였다. 사후분석 결과 의미 유창성 중 ‘동물’ 범주에서는 연소노인과 고령 노인의 전환수 차이만 유의한 것으로 나타났으며, '가게 물건' 범주에서는 연소노인과 중간노인에서만 유의한 차이가 있었다. 마지막으 로 의미 유창성 과제에서는 반복오류의 빈도가 가장 높았으며, 음소 유창성 과제에서는 기타오류의 빈도가 가장 높은 것으로 나타났 다. 논의 및 결론: 본 연구의 결과를 통하여 노화에 따라 구어 유창성 과제의 수행력 및 군집과 전환 특성의 차이가 있음을 알 수 있다.

핵심어: 노화, 구어 유창성, 군집, 전환

이 논문은 2019년 대한민국 교육부와 한국연구재단의 지원을 받아 수행된 연구임 (NRF-2019S1A5A2A01035719).

\section{참고문헌}

강연욱, 진주희, 나덕렬, 이정희, 박재설 (2000). 통제단어연상검사(Controlled Oral Word Association Test)의 노인 규준 연구. 한국심리학회지: 임상, 19(2), 385-392.

강연욱 (2006). K-MMSE (Korean-Mini Mental State Examination)의 노인 규준 연구. 한국 심리학회지: 일반, 25(2), 1-12.

기영옥 (2006). 정상 노인층의 구어 유창성 오류 정도 및 특성. 연세대학교 대학원 석사학위논문.

김정완, 황재호, 김수련, 김향희 (2013). 정상 노인의 연령에 따른 주의력 및 이름대기 능력의 차이. 언어치료연구, 22(3), 25-44.

김지연 (2016). 장· 노년층의 생성이름대기 영향 요인: 작업기억, 집행기능, 교육년수를 중심으로. 연세대학교 대학원 석사학위논문. 김향희, 허지회, 김덕용, 김정완 (2009). 실어증 선별검사(Screening Test for Aphasia Neurologic communication Disorders, STAND). 학지사. 박재설, 강연욱, 장은주, 오은아, 유경호, 이병철 (2006). 혈관성 치매와 알츠하이머형 치매의 단어 유창성 비교: 군집화와 전환. 언어청각장애연구, 11(3), 99-112.

박제준, 윤지혜 (2015). 생성이름대기를 통한 정상 노인의 단어 찾기 책략 특성. 재활복지, 19(2),339-360.

이수정 (2019). 난청 노년층의 단어 유창성에 나타난 군집과 전환 특성. 한국청각언어재활학회, 15(4), 293-301.

조맹제, 배재남, 서국희, 함봉진, 김장규, 이동우, 강민희(1999). DSM-III-R 주요우울증에 대한 한국어판 Geriatric Depression Scale(GDS)의 진단적 타당성 연구. 신경정신의학, 38(1), 48-63.

최현주 (2008). 노인성 알츠하이머병 위험군과 초기 알츠하이머병 환자의 이름대기와 구어 유창성능력의 비교. 음성과학, 15(2), 111-118. 최현주 (2011). 구어유창성과 그림설명과제를 통한 경도인지장애(MCI) 환자의 언어손상 검출. 언어청각장애연구, 16(2), 171-184. 최현주 (2012). 고령자의 구어 유창성 과제 수행력: 범주별 성별 및 교육정도에 따른 차이. 언어치료연구, 21(2), 37-52.

\section{ORCID}

김주영(제1저자, 언어재활사 https://orcid.org/0000-0003-4888-766X); 최현주(교신저자, 교수 https://orcid.org/0000-0003-4654-3206) 